Literature Review

\title{
Management of Abnormal Cervical Cytology: Atypical Squamous Cells of Undetermined Significance (ASC-US) and Atypical Squamous Cells cannot exclude High Grade Intraepithelial Lesion (ASC-H)
}

\author{
Manajemen Sitologi Abnormal Serviks: Atypical Squamous Cells of Undetermined \\ Significance (ASC-US) and Atypical Squamous Cells can not Exclude High Grade \\ Intraepithelial Lesion (ASC-H)
}

\author{
Fitriyadi Kusuma, Mediana S Liedapraja \\ Department of Obstetrics and Gynecology \\ Faculty of Medicine University of Indonesia/ \\ Dr. Cipto Mangunkusumo Hospital
}

Jakarta

\begin{abstract}
Objective: To review for the management of abnormal cervical cytology: atypical squamous cells of undetermined significance (ASCUS) and atypical squamous cells cannot exclude high-grade intraepithelial lesion (ASC-H) as a treatment of cervical precancerous lesions in order to avoidexcessive treatment, reduce of unnecessary examinations and to provide cost effectively.

Method: Literature study on published literatures and studies about the management of cervical cytology.

Conclusion: The results of ASC-US cervical cytology and ASC-H is aninitial screening to detect precancerous cervical lesions. Definitive therapy should be done when finding a low-grade lesions (LSIL) and high degree of lesion(HSIL) squamous intraepithelial. A clinician expected to understand the natural history of HPV infection and the management of precancerous cervical lesions properly.

[Indones J Obstet Gynecol 2013; 37-3: 166-170]

Keywords: ASC-H, ASC-US, cervical cytology abnormalities, cervical precancerous lesion.
\end{abstract}

\begin{abstract}
Abstrak
Tujuan: Sebagai telaah untuk mengevaluasi keputusan klinis dalam tatalaksana hasil sitologi abnormal serviks:a typical squamous cells of undetermined significance (ASC-US) dana typical squamous cells can not exclude high-grade intraepithelial lesion (ASC-H) sebagai terapi lesi prakanker serviks untuk menghindari tatalaksana berlebih, mengurangi pemeriksaan yang tidak perlu dan memberikan biaya yang lebih efektif.
\end{abstract}

Metode: Telaah pustaka dari berbagai literature dan penelitian mengenai tata laksana hasil sitologi serviks.

Kesimpulan: Hasil dari sitologi serviks ASC-US dan ASC-H merupakan suatu skrining awal dalam mendeteksi adanya lesi prakanker serviks. Terapi definitif sebaiknya dilakukan bila ditemukan adanya lesi derajat rendah (LSIL) dan lesi derajat tinggi (HSIL) intra epithelial sel skuamosa. Seorang klinisi diharapkan memahami riwayat infeksi HPV dan manajemen lesi prakanker serviks yang tepat.

[Maj Obstet Ginekol Indones 2013; 37-3: 166-170]

Kata kunci: ASC-H, ASC-US, lesi prakanker serviks, sitologi abnormal serviks.

Correspondence: Mediana S Liedapraja, Division of Oncology. Department of Obstetrics and Gynaecology, Faculty of Medicine University of Indonesia Jakarta. Telephone: 085218460698, email: medi_goto88@hotmail.com

\section{INTRODUCTION}

Management of patients with atypical squamous cells of undetermined significance (ASC-US) and atypical squamous cells cannot exclude high-grade intraepithelial lesion (ASC-H) remains controversial. The guidelines incorporate the Bethesda system 2001 terminology and triage study: immediate colposcopy, triage based on HPV DNA testing, and repeat cytology at 6 to 12 months intervals. The American College of Obstetricians andGynecologists has published recommendationsfor management of abnormalcervical cytology findings.
Cervical cytology abnormalities lead to precancerous lesion by infection of human papillomavirus (HPV) through sexual transmission. HPV Infection of cervical epithelial, viral persistence, progression and persistent infection likely reflect to higher risk of cervical cancer. Cervical cancer was the third most common cancer in women, estimated 530,000 new cases and 275,000 women deaths due to cervical cancer worldwide in 2008. About 85\% cervical cancer cases occur in developing countries. Proper early detection and management of precancerous lesion as an effort to prevention and reduction number of cervical cancer. 


\section{Natural History of Human Papilloma Virus Infection}

Human Papilloma Virus (HPV) is DNA virus generally infect the mucosa or cutaneous epithelium. Virus entersthrough inflammation or trauma into the basal cell layer and express their genes and begin process to replication. Integration of HPV DNA disrupts early (E1/E2) viral genes regulatory leading to increased expression of E6 and E7, whereas these genes have ability to inhibit tumor suppressor genes (p53 and retinoblastoma gene/pRB) that induce abnormalities of cell proliferation, histologic features and cellular immortalization. Subsequently, Late viral genes (LI and L2) are expressed to form structural protein that responsible to DNA packaging and virionsassembly. Final differentiation of epithelial cells produce new infectious virions and release of infectious virus shed through cell desquamation. ${ }^{1}$

\section{Prevalence of Human Papilloma Virus In- fection}

Genital HPV infection is the most common sexual transmitted disease among in women. Prevalence of HPV infection ranges from $2-44 \%{ }^{2}$ The prevalence of abnormal cervical cytology relatively high in adolescents, with rates of ASC-US ranging from 10\%-13\%, LSIL 3\%-9\% and HSIL $0.7 \%-3 \%$ The prevalence of invasive cervical cancer is low in women with ASC-US (approximately 0.1-0.2\%). ${ }^{3}$

The peak prevalence of HPV infection in women younger than 25 years with rate 20\%-25\% and start falling in 30 years with rate around $10 \%$ (remains stable into 60 years). A recent report in the United States showed $40 \%$ of women aged 14 to 19 years were infected with HPV and $49.3 \%$ sexually active women aged 20 to 24 years had HPV but prevalence dropped over 24 years of age. 4 Studies in United States showed approximately $25 \%$ of older women were infected $27.8 \%$ of 25 29 year olds, $27.3 \%$ of $30-39$ year olds, $23.9 \%$ of 40-49 year olds and $20.2 \%$ of $50-59$ year olds). ${ }^{5}$

\section{Role Human Papilloma Virus Infection in Cervical Cancer}

Epidemiological studies show there is a strong association between high risk HPV infection and cer- vical cancer. More than 100 types of HPV have been identified and 25 types infect the genital tract. HPVs are classified as low risk and high risk types. (wheeler. 2008) Infection of low risk HPV types 6,11 (6 and 11) can regress spontaneously but persistent infection associated with development of benign lesion of genital warts. Persistent infection of high risk HPV(16,18,31,33,35,39,45,51,52,56,58,59,73 and 82) have greater risk of moderate or severe cervical dysplasia which associated with development of cervical cancer. 6,7

HPV is a transient infection for most women, the duration of most infections generally 7-10 months (Ho GY. N Engl J Med.1998) and within 3 years of observations $70-93 \%$ become undetectable or regression. Women who show persistence infection remain at risk for the development of cancers. Multiple factors influence the development of cancer include behavioral (multiple partners, early age of first sexual intercourse and immunosuppression condition). Final mechanisms of development cervical cancer are not well understood, suggest disruptions cell cycle and telomerase are the key factors and oncogenic properties of HPV because E6 and E7 enhance p53 degradation. E6 induce activates of telomerase (telomere lengthening enzyme) leading to cellular immortalization and E7 also block cells to apoptosis.

\section{Cervical Cytologic of ASC-US}

Thereare several classifications of cervical cytology terminology such as Papaniculaou classification, Reagan classification (a typical, milddy splasia, moderate dysplasiaand severe dysplasia), Richart classification (CIN1, CIN2 and CIN3), and the new classification of the Bethesda System. The Bethesda System was update in 2001 to clarify cervical cytology results. ${ }^{8}$ The Bethesda System (TBS) is the standard classification system used for reporting Pap test results and to promote effective communication of cytology results from cytopathologist and clinician. This system classifies as squamous cell abnormalities suggestive of intraepithelial lesions (ASC-US and ASC-H), squamous intraepithelial lesion (LSIL and HSIL) and squamous cell carcinoma and the World Health Organization (WHO) classifies as atypia, condyloma, cervical intraepithelial neoplasia (CIN1, CIN 2, CIN 3), carcinoma in situ and squamous cell carcinoma. ${ }^{4}$ 
Table 1. Classifications of cervical cytology terminology

\begin{tabular}{|c|c|c|c|c|c|c|c|c|}
\hline \multirow{2}{*}{$\begin{array}{l}\text { Papaniculaou } \\
\text { Reagan }\end{array}$} & \multirow{2}{*}{$\begin{array}{c}\text { Class } 1 \\
\text { Normal }\end{array}$} & \multirow{2}{*}{$\begin{array}{l}\text { Class } 2 \\
\begin{array}{l}\text { Inflammation/ } \\
\text { Inconclusive }\end{array}\end{array}$} & & \multicolumn{2}{|c|}{ Class 3} & \multicolumn{2}{|c|}{ Class 4} & \multirow{2}{*}{$\begin{array}{r}\text { Class } 5 \\
\text { Cancer }\end{array}$} \\
\hline & & & & $\begin{array}{l}\text { Mild } \\
\text { Dysplasia }\end{array}$ & $\begin{array}{l}\text { Moderate } \\
\text { Dysplasia }\end{array}$ & $\begin{array}{l}\text { Severe } \\
\text { Dysplasia }\end{array}$ & CIS & \\
\hline Richart & Normal & Atypia & & CIN 1 & CIN II & CIN III & CIN III & Cancer \\
\hline Bethesda 1991 & Normal & $\begin{array}{l}\text { Benign } \\
\text { Cellular } \\
\text { Changes }\end{array}$ & ASCUS & LGSIL & HGSIL & HGSIL & HGSIL & Cancer \\
\hline Bethesda 2001 & Normal & ASC-US/ASC-H & & LGSIL & HGSIL & HGSIL & HGSIL & Cancer \\
\hline
\end{tabular}

There are several classifications of cervical cytology terminology such as Papaniculaou classification, Reagan classification (a typical, milddy splasia, moderate dysplasia and severe dysplasia), Richart classification (CIN1, CIN2 and CIN3), and the new classification of the Bethesda System.

The cytopathologist act as a guide for the clinician to have satisfactory management of ASC-US so hope the cytopathologist and clinician must communicate clearly and frequently to any suspicious regarding the changes occurring in the cervix when a smear has reported as ASC-US. ${ }^{9}$ ASC used to describe cellular abnormalities that suggestive of SIL but are not able to definitively diagnosed as SIL. ASC-US is considered to benign lesions, cytology criteria of ASC-US include loss of normal nuclear/cytoplasm ratio due to nuclear enlargement and nuclear hyperchromatic. Atypical squamous cells cannot exclude HSIL (ASC-H) is associated with an increasing predictive value for detecting a more serious lesion.The diagnosis of ASC-H on Pap smear is associated with an appreciable risk of clinically significant disease. Patients with an ASC$\mathrm{H}$ Pap smear result should undergo timely colposcopic and histologic assessment to rule out HSIL, and cervical cancer. ${ }^{10}$

\section{HPV Testing as an Adjunct to Cervical Cy- tology}

Cervical cytology screening has been successful in reducing rates of cervical cancer, but there are limitations to the use cytology which characterized by errors in sampling, slide preparation, classification of results, interpretation and categorizes cytology results. HPV as adjunct to cytology has approved by FDA, use of HPV testing as triage strategy is highly sensitive, specific, effective and potentially economical as an adjunct to ASC-US cytology as primary screening and detectionfor severe dysplasia. ${ }^{11}$ Cytology and HPV testing have a sensitivity and specificity of 91\%, National Cancer Institute, ASCCP and the American Cancer Society concluded that the use of adjunctive HPV testing for women over 30 years was an acceptable strategy.12 HPV testing in women with ASCUS has a negative predictive value of $99.5 \%$, meaning that if an HPV test has a negative result, it is highly unlikely that disease is present. ${ }^{13}$

Rates of HPV DNA positivity are much higher in younger compared with older women with ASCUS. ${ }^{14,15}$ Using HPV testing to manage adolescent with ASC-US would refer women at risk to colposcopy. Conservative follow-up with repeat cytology and HPV testing at 12 months appears to be the best management approach for cytology negative and HPV positive women. Women who on repeat testing are persistently HPV positive should undergo colposcopy, whereas women negative on both tests can be rescreened in 3 years. ${ }^{16}$

\section{Management of women with ASC-US}

Three major management strategies have been used inthe United States for management of women with ASCUS cervical cytology: immediate colposcopy, triage based on HPV DNA testing, and repeat cytology at 4- to 6-month intervals. ${ }^{17} \mathrm{Ma}-$ nagement guidelines for women with abnormal cytology results based on the 2001 Bethesda system which sponsored by American Society for Colposcopy and Cervical Pathology (ASCCP), collaborate and integrated terminology and management guidelines provide more effective of women with cervical abnormalities. ${ }^{8}$ Management guidelines recognized 3 management strategies for women 
with ASC-US according to a large, prospective, multicenter and randomized trial by National Cancer Institute. ${ }^{15,16}$

Clinical data have demonstrated that 2 repeat cytology examinations performed at 6 months interval, testing for HPV and colposcopy examination are all safe and effective apptoaches to managing women with ASC-US. ${ }^{17}$ HPV triage does not efficient in young patient with ASC-US. ${ }^{4}$

Management of ASC-US in women 20 years and older include three acceptable follow up approaches, including monitoring every 6 months for a year, referral to immediate colposcopy and testing for HPV DNA. Adolescents women 20 years and younger are considered separately from women 21 and older in guidelines for the management abnormal cytology. In adolescents, ASC-US or LSIL detected by screening should be monitored with repeated cytology every 12 month, if at the first 12 month follow up (HSIL or ASC-H) is detected, patient should be referred to colposcopy for biopsy. If at the first 12 month follow up (normal, or LSIL or ASCUS) is detected, patient continue monitored. Routine screening should resume if cytology normal at the second 12 month follow up (at 24 months). If at 24 months cytology shows LSIL, ASCUS, ASC-H or HSIL, patient should be referred to colposcopy. ${ }^{18}$

\section{ASC-US in immunosuppressed, postmeno- pausal women and pregnancy}

All immunosuppressed, postmenopausal women and HIV women with ASC-US undergo colposcopy, and should be managed in the same manner as women in the general population regardless of anti-retroviral therapy.12,16 Management options for pregnant women over 20 years old with ASC-US are same as nonpregnant women, with the exception that it is acceptable to defer colposcopy until at least 6 weeks postpartum. ${ }^{16}$

\section{Management of women with ASC-H}

Regardless of age, Women with ASC-H should prompt a referral to colposcopy, If high grade lesion not identified follow up with cytology testing at 6 and 12 months or HPV DNA test at 12 months is acceptable. Referral to colposcopy is recommended for women with positive HPV DNA or have ASC-US or greater on their repeat cytologic tests.
If the HPV DNA test is negative or if 2 consecutive repeat cytologic tests are negative for intraepithelial lesion or malignancy, routine cytologic screening is recommended.If Colposcopy evaluation identified high grade lesion (CIN 2 and 3 by histopathology), manage per ASCCP guideline is recommended. .,16 $^{2}$

\section{CONCLUSION}

Cervical cytology results of ASC-US and ASC-H are a terminology in screening cells, where the cells could not be categorized as low-grade (CIN1, mild dysplasia), or normal. ASC-US andASC-H could only be used as a screening and not a diagnostic modality. Definitive therapy should only be made based on the results of histopathology and further examination. Appropriate treatment help physicians to prevent excessive therapy and inadequate therapy.

\section{REFERENCES}

1. Doorbar J. Molecular biology of human papillomavirus infection and cervical cancer. Clinical science. 2006; 110(5): 525-41. PubMed PMID: 16597322.

2. Trottier H, Franco EL. The epidemiology of genital human papillomavirus infection. Vaccine. 2006; 30: 24 Suppl 1: S115. PubMed PMID: 16406226.

3. Jones BA, Novis DA. Follow-up of abnormal gynecologic cytology: a college of American pathologists Q-probes study of 16132 cases from 306 laboratories. Archives Pathol Lab Med. 2000; 124(5): 665-71. PubMed PMID: 10782145.

4. Widdice LE, Moscicki AB. Updated guidelines for papanicolaou tests, colposcopy, and human papillomavirus testing in adolescents. The Journal of adolescent health: official publication of the Society for Adolescent Medicine. 2008; 43(4 Suppl): S41-51. PubMed PMID: 18809144. Pubmed Central PMCID: 2938015.

5. Dunne EF, Unger ER, Sternberg M, McQuillan G, Swan DC, Patel SS, et al. Prevalence of HPV infection among females in the United States. JAMA. 2007; 28: 297(8): 813-9. PubMed PMID: 17327523.

6. Ho GY, Bierman R, Beardsley L, Chang CJ, Burk RD. Natural history of cervicovaginal papillomavirus infection in young women. N Eng J Med. 1998; 12; 338(7): 423-8. PubMed PMID: 9459645.

7. Kjaer SK, van den Brule AJ, Paull G, Svare EI, Sherman ME, Thomsen BL, et al. Type specific persistence of high risk human papillomavirus (HPV) as indicator of high grade cervical squamous intraepithelial lesions in young women: population based prospective follow up study. BMJ. 2002; 14; 325(7364): 572. PubMed PMID: 12228133. Pubmed Central PMCID: 124551.

8. Solomon D, Davey D, Kurman R, Moriarty A, O'Connor D, Prey M, et al. The 2001 Bethesda System: terminology for reporting results of cervical cytology. JAMA. 2002; 24; 287(16): 2114-9. PubMed PMID: 11966386. 
9. Kaufman RH. Atypical squamous cells of undetermined significance and low-grade squamous intraepithelial lesion: Diagnostic criteria and management. Am J Obstet Gynecol. 1996; 175(4): 1120-8.

10. Barreth D, Schepansky A, Capstick V, Johnson G, Steed H, Faught W. Atypical squamous cells-cannot exclude highgrade squamous intraepithelial lesion (ASC-H): a result not to be ignored. Journal of obstetrics and gynaecology Canada: JOGC = Journal d'obstetrique et gynecologie du Canada: JOGC. 2006 Dec; 28(12): 1095-8. PubMed PMID: 17169233.

11. Kulasingam SL, Hughes JP, Kiviat NB, Mao C, Weiss NS, Kuypers JM, et al. Evaluation of human papillomavirus testing in primary screening for cervical abnormalities: comparison of sensitivity, specificity, and frequency of referral. JAMA. 2002; 288(14): 1749-57. PubMed PMID: 12365959.

12. Kirby TO, Huh WK. HPV Triage of Patients with ASCUS Cervical Pap Smears. Sexuality, Reproduction \& Menopause. 2004; 2(3). Epub September 2004. Elsevier.

13. Solomon D, Schiffman M, Tarone R, Group FtA. Comparison of Three Management Strategies for Patients With Atypical Squamous Cells of Undetermined Significance: Baseline Results From a Randomized Trial. J Nat Cancer Inst. 2001; 93(4): 293-9.
14. Boardman LA, Stanko C, Weitzen S, Sung CJ. Atypical squamous cells of undetermined significance: human papillomavirus testing in adolescents. Obstet Gynecol. 2005; 105(4): 741-6. PubMed PMID: 15802399.

15. Sherman ME, Solomon D, Schiffman M, Group ALTS. Qualification of ASCUS. A comparison of equivocal LSIL and equivocal HSIL cervical cytology in the ASCUS LSIL Triage Study. Am J Clin Pathol. 2001; 116(3): 386-94. PubMed PMID: 11554167.

16. Wright TC, Massad LS, Dunton CJ, Spitzer M, Wilkinson EJ, Solomon D. 2006 consensus guidelines for the management of women with abnormal cervical cancer screening tests. Am J Obstet Gynecol. 2007; 197(4): 346-55.

17. Group A-LTS. Results of a randomized trial on the management of cytology interpretations of atypical squamous cells of undetermined significance. Am J Obstet Gynecol. 2003; 188(6): 1383-92. PubMed PMID: 12824967.

18. Kahn JA, Hillard PJ. Cervical Cytology Screening and Management of Abnormal Cytology in Adolescent Girls. J Pediat Adol Gynecol. 2003; 16(3): 167-71. 